\title{
The Book Everybody Read: Vernacular Translations of Sacrobosco's Sphere in the Sixteenth Century
}

Journal for the History of Astronomy 20I5, Vol. 46(I) 4-28

(C) The Author(s) 2015

Reprints and permissions: sagepub.co.uk/journalsPermissions.nav DOI: $10.1177 / 0021828614567419$ jha.sagepub.com @SAGE

\section{Kathleen Crowther}

University of Oklahoma, Department of the History of Science, USA

\section{Ashley Nicole McCray}

University of Oklahoma, Department of the History of Science, USA

\section{Leila McNeill}

Independent scholar, Texas, USA

\section{Amy Rodgers}

University of Oklahoma, Department of the History of Science, USA

\section{Blair Stein}

University of Oklahoma, Department of the History of Science, USA

\begin{abstract}
This article presents four detailed case studies of sixteenth-century vernacular translations of Sacrobosco's De sphaera. Previous scholarship has highlighted the important role of Sacrobosco's Sphere in medieval and early modern universities, where it served as an introductory astronomy text. We argue that the Sphere was more than a university teaching text. It was translated many times and was accessible to a wide range of people. The popularity of the Sphere suggests widespread interest in cosmological questions. We suggest that the text was a profitable one for early modern printers, who strove to identify books that would be reliable sellers. We also argue that the Sphere was not a static text. Rather, translators and editors added commentaries and other supplemental material that corrected and updated Sacrobosco's original text and
\end{abstract}

\section{Corresponding author:}

Kathleen Crowther, Department of the History of Science, University of Oklahoma, 60I Elm Avenue, Room 625, Norman, OK 73019, USA.

Email: kcrowther@ou.edu 
demonstrated the practical utility of this information. We contend that the Sphere was actually an important vehicle for disseminating new information about the cosmos.

\section{Keywords}

Joannes de Sacrobosco, De sphaera, Sphere, vernacular translations, history of printing, history of the book, popular science

Sometime around 1230, Johannes de Sacrobosco (ca. 1200 - ca. 1250), a teacher at the University of Paris, composed an introductory astronomy textbook for his students. In this small text, known as the Sphere (De sphaera), Sacrobosco offered a concise and non-technical description of the geocentric model of the cosmos derived from ancient Greek and medieval Arabic scholars. He explained the structure and motions of the heavens, especially the motions of the sun, moon and fixed stars. He also gave the dimensions of the earth, the size of the oceans, and the latitudes of different climactic zones. ${ }^{1}$ The Sphere has the distinction of being one of the most successful scientific texts ever written. Within a few decades of its composition, it became the most popular and widely used astronomy textbook in Europe, serving as the basis for introductory astronomy lectures at universities from the mid-thirteenth to the end of the seventeenth century. As astronomy was part of the basic arts curriculum that all students had to complete before advancing to any of the higher faculties, a very high percentage of university-educated men would have been exposed to this text. According to the most recent estimates, there were over 200 different editions of the Sphere printed between 1472 and $1673 .^{2}$

The Sphere was widely used outside of the university context as well, and the text was translated into numerous vernacular languages, including German, French, Italian, English, Spanish and Portuguese. There were at least thirty vernacular editions printed. ${ }^{3}$ Although we exaggerate in calling it "the book everybody read," it was certainly one of the most widely read scientific books of all time. ${ }^{4}$

Despite its enormous popularity and longevity, the Sphere has attracted little attention from historians of science. Lynn Thorndike, Olaf Pedersen and Owen Gingerich have discussed the contents of Sacrobosco's text and described its importance as a teaching text in medieval and early modern universities. ${ }^{5}$ We contend that the Sphere had a much greater role in cosmological debate than its rather humble role as a university textbook would suggest. During the more than four centuries that Europeans read, copied, translated and printed the Sphere, there were dramatic changes in understandings of the heavens and the earth. The Portuguese and Spanish voyages of exploration beginning in the fifteenth century challenged Sacrobosco's claims that the torrid zone (the region around the equator) was uninhabitable and that over three-quarters of the globe were covered by water. The sixteenth and seventeenth centuries were a period of revolutionary discoveries and innovations in astronomy, most famously, of course, the rise of heliocentric models of the cosmos. The Sphere did not remain static in the midst of these intellectual upheavals. Indeed, almost all versions of the Sphere produced after Sacrobosco's lifetime contain commentary or other supplemental material (including prefaces and additional sections). 
This material expanded, corrected and updated the original text of Sacrobosco. The Sphere was actually an important vehicle for disseminating and discussing new discoveries and ideas about the cosmos. ${ }^{6}$

We also contend that the Sphere had a much larger audience than university students alone. This was especially true after the invention of printing in the mid-fifteenth century. In fact, to understand the long-running success of the Sphere, it is necessary to set it within the context of the history of the printed book. ${ }^{7}$ The earliest printed editions of the Sphere appeared in the 1470s. These were Latin editions; the first printed vernacular versions appeared in the first decade of the sixteenth century. ${ }^{8}$ Not all manuscript texts made it into print, of course, and very few flourished as long as the Sphere did. The success of Sacrobosco's modest little book reflects its unique combination of tradition and novelty. As Andrew Pettegree explains, the print market was extremely competitive and most books required a significant initial outlay of money to produce. Any book that did not offer a good return on this initial investment could mean financial ruin for the printer. Therefore, "there was always a temptation to make conservative choices, printing proven bestsellers, or books for which there was a steady recurrent demand." However, this strategy could backfire because if there were too many editions of a book on the market, no printer could make enough profit from them. ${ }^{9}$ Printers needed books for which there was proven demand, but they also needed to make editions that were in some way distinctive to distinguish them from their competitors. The Sphere met these criteria admirably. For Latin versions, university students formed a small but steady audience. Because most educated people wanted at least a basic understanding of the cosmos, the book was also appealing to men and women who could read Latin, even if they did not formally study at a university. Over the course of the sixteenth century, printers sought to expand this audience by publishing versions with additional material, most notably commentaries, which they could market as "new and improved."

Further, printers sought to reach the growing numbers of people who could read a vernacular language but not Latin. ${ }^{10}$ Printers and translators modified the Sphere in various ways to suit the needs, tastes and desires of different readers. In particular, many translators sought to make the book appeal to a broad audience by emphasizing the utility of Sacrobosco's text, and some included sections on practical subjects like astrology, cartography and navigation. Vernacular translations of the Sphere often have prefaces in which the translator claims the altruistic desire to make knowledge of the cosmos accessible to those who cannot read Latin. While such motivations may indeed have been operative, economic considerations clearly played a role as well. No printer took on the Sphere solely to enlighten his or her fellow men and women. ${ }^{11}$

We focus in this essay on four sixteenth-century vernacular spheres - one in German, one in French, one in Italian, and one in English. Each of these includes a translation of Sacrobosco's Sphere and additional material added by the translator or by the printer. These four examples, from four different regions and in four different languages, illustrate the range of material that was added to spheres, including discussions of the work of recent astronomers like Georg Peuerbach (1423 - 1461) and Nicholas Copernicus (1473 - 1543), geometry problems for the reader to solve, and descriptions of newly discovered regions of the world. Further, these four examples substantiate our point that in the case of vernacular spheres there is frequently an emphasis on utility. The German 
and French spheres we discuss in this article both contain material on astrology. The French and Italian spheres contain material on voyages of discovery. And the English sphere contains material relevant to both of these topics.

The four spheres that we discuss in this article were part of a broader trend, a growing demand for scientific works in vernacular languages in the sixteenth century. Scientific books in the vernacular included both works originally composed in a vernacular and those translated from Latin. In his sweeping study of the history of Western translation, Henri Van Hoof notes the popularity in the sixteenth century of translations of works on "astrology and mathematics, medicine and agriculture, history and geography." 12 Most studies of the rise of vernacular scientific publishing in the early modern period focus on one particular country or region. So, for example, Violaine Giacomotto-Charra and Isabelle Pantin document the rising interest in vernacular astronomical texts in France in this period. Giacomotto-Charra describes the 1550 s as a moment "which saw in general a marked renewal of interest in questions linked to the sky" that inspired "a sudden and rapid wave of French translations." 13 Isabelle Pantin comments on the "exceptional diffusion" of Sacrobosco in France in the sixteenth century. ${ }^{14}$ In the German context, Miriam Chrisman's study of printing and reading in Strasbourg demonstrates the increase in publication of vernacular scientific and medical books beginning in the late $1520 \mathrm{~s} .{ }^{15}$ And Deborah Harkness has analyzed the sharp rise in the publication of mathematical works in English in the second half of the sixteenth century. ${ }^{16}$ We draw on these studies of particular regional print markets in this essay, and we point to several similarities in the production and demand for scientific books across Europe in different vernaculars. Our study of vernacular spheres shows that printers across Europe were keen to encourage and profit from the demand for vernacular scientific texts, and that printers frequently played a key role in the production of such texts. In three of our examples - the German, French and English spheres - the printers made important decisions about the format and content of the book. Accordingly, we take the context and motivations of the printers as well as the translators into account in our discussion of each sphere.

We will discuss our four examples in chronological order, based on date of publication. When referring to Sacrobosco's original text, we use the term Sphere. When referring to later editions in either Latin or the various vernaculars we use the term sphere, or the plural spheres. Although we highlight some of the similarities between our four examples, we also emphasize that each was produced by different individuals, in a specific local context, and often with particular readers in mind. Each of these spheres is thus a unique text.

\section{Conrad Heinfogel's Sphera materialis}

Our first example of a vernacular sphere is a German translation by Conrad Heinfogel (ca. 1455-1517). Heinfogel's translation was first published in Nuremberg in 1516, and went through three more editions, one in Cologne (1519) and two in Strasbourg (1533 and 1539). ${ }^{17}$ This is one of the very earliest printed vernacular spheres. ${ }^{18}$ There were two earlier German translations of Sacrobosco's Sphere made in the second half of the fourteenth century, but they were not printed. ${ }^{19}$ Heinfogel was educated at the University of Erfurt. He took holy orders in 1480, and eventually became chaplain to Holy Roman 
Emperor Maximilian I (1459 - 1519). ${ }^{20}$ Heinfogel was part of a group of humanist intellectuals in his native city of Nuremberg and at the court of the Emperor Maximilian, and he wrote or collaborated on a number of astronomical and cartographic projects. In 1503, Heinfogel, along with Sebastian Sperantius, Bishop of Brixen, (d. 1525) ${ }^{21}$ and Dietrich Ulsen (d. 1508), ${ }^{22}$ a physician, created celestial maps of the northern and southern hemispheres. These maps later served as the template for Albrecht Dürer's (1471 - 1528) famous star charts published in $1515 .{ }^{23}$ Dürer created his maps under the patronage of Maximilian I and in collaboration with Heinfogel, who provided star positions that were updated and corrected from his 1503 maps, and Johannes Stabius (1450-1522), a mathematician, cartographer, court historian, and adviser to Maximilian I, who ordered and edited the charts. ${ }^{24}$ In 1514, Heinfogel published a new Latin translation of Ptolemy's Geographia, ${ }^{25}$ and in 1515 he compiled and published an almanac. His translation of Sacrobosco's Sphere was his last work.

In his translation, Heinfogel sought to render the book more accessible, and perhaps more engaging, to German readers by using German rather than Latin words whenever possible. For example, Heinfogel usually gives the planets and the constellations their German names. So strong was his preference for German vocabulary that he also invented German words for technical astronomical terms like solstices (Sonnenwende), equinoxes (Ebennechte), horizon (Augenender), and meridian (Mittentager-Creis). One of his most striking neologisms is his word for astrolabe. "In German," he writes, "this is called the 'lips of the stars' [sternenlebs] because, just as the mouth and lips declare what is hidden in the heart, so the lips of the stars [the astrolabe] reveal the secrets of the stars." 26 Heinfogel believed the Latin word astrolabium (astrolabe) was derived from the words aster (star) and labia (lips). In fact, the suffix -labium (or -labus in classical Latin) denoted a measuring instrument.

Heinfogel's translation stays close to Sacrobosco's original Latin, and he added no commentary to the text, other than the explanations of unfamiliar terms like astrolabe. However, he did add a preface and a poem in which he claimed that he made his translation of Sacrobosco "for the sake of those who do not know Latin, and yet desire to learn this book's Kunst." 27 The German word Kunst connotes both theoretical knowledge and practical know-how. The seven liberal arts are "Künste" in German, but craft skills are also "Künste." 28 Although Heinfogel's use of the term Kunst pointed to both the theoretical and practical dimensions of cosmological knowledge, he confined himself to translating Sacrobosco's text and did not add material that explained how knowing the "course of the heavens" (himels lauff) might be put to practical use. ${ }^{29}$ As we will see, many later translators did add such information. In his preface, Heinfogel described Sacrobosco's Sphere as providing a foundation (fundament), one that he implies interested readers could build on if they chose. ${ }^{30}$

Heinfogel's Sphaera materialis illustrates the mixture of intellectual and economic motivations at play in the production of vernacular spheres. For Heinfogel, it was one of a number of scientific projects: he made star maps, composed an almanac and translated Ptolemy from Greek into Latin. These projects were conducted under the patronage of the Emperor Maximilian I, and Heinfogel was part of a circle of intellectuals and artists at the Emperor's court who were engaged in similar activities. Three different printers in three different German cities printed editions of Heinfogel's sphere. While the first, Jobst 
Gutknecht (fl. 1514 - 42) of Nuremberg, ${ }^{31}$ probably worked directly with Heinfogel, the last two printers, Arnd von Aich (d. ca. 1530) of Cologne ${ }^{32}$ and Jacob Cammerlander (1500 - 1549) of Strasbourg, printed the Sphera materialis after Heinfogel's death. They are examples of printers choosing to publish a profitable existing text as part of an expanding market for vernacular science. Cammerlander, who published Heinfogel's sphere twice, actually specialized in scientific texts in German.

Cammerlander was a Lutheran who had been imprisoned in his native Mainz for printing and circulating Lutheran works. He relocated to the more congenial environment of Strasbourg and opened a print shop in $1531 .{ }^{33}$ Cammerlander's printing profile reflects a wide range of topics and genres, but scientific texts made up the majority of his shop's output, perhaps because they were less controversial than religious polemics. Between 1531 and 1548, scientific texts constituted fifty-four percent of the books he printed. These texts included calendars, prognostications, two books on astrological medicine, a wide variety of technical manuals, and various astronomical works, including Heinfogel's translation of Sacrobosco. ${ }^{34}$ Most of the scientific books Cammerlander printed had practical information, medical, technical or astrological. Cammerlander (or someone working for him) added a section on astrology to the last edition of the Sphera materialis. This addition would have given the German sphere a more utilitarian character, by demonstrating how knowledge of the heavens could be put to practical uses. The addition of astrological material also distinguished the 1539 edition from the earlier edition, which may still have been on the market, perhaps giving the last edition a competitive edge.

The additional section on astrology in the last edition of Heinfogel's sphere included a discussion of each of the twelve signs of the zodiac and each of the seven planets (the moon, Mercury, Venus, the sun, Mars, Jupiter and Saturn) and their influences on the terrestrial realm and on human beings. For example, we read of the sign Virgo (Junckfraw) that it is "cold and dry" and "rules over melancholy, the dry and cold earthy complexion." It has influence over "the intestines and the stomach." 35 The planet Mercury is "cold and moist" and those born under its influence are inclined to the "noble arts, like rhetoric, geometry [and] philosophy." 36 The longest entry is for the sun, and it explains how the seasons change as the sun moves around the earth through the signs of the zodiac:

In March the sun is in Aries and the earth germinates. Roots, trees and leaves turn green, brooks and waters flow, and people are very much inclined to love making because this is the time when the moisture in the blood increases. ${ }^{37}$

The information in this additional section is not sufficient to enable the reader to cast horoscopes or make sophisticated prognostications about the weather, the course of a disease, or the outcome of political intrigue, but it gives a general sense of the influence of the stars and planets on human life and health.

The preceding discussion of Conrad Heinfogel, Jacob Cammerlander and the various editions of the Sphera materialis points to three important features of early modern vernacular spheres. First, translation itself subtly altered the text, even without the addition of commentary or other supplemental material. Heinfogel created a new technical 
vocabulary of astronomical terms in German. Further, his repeated use of the word Kunst, which had the dual sense of science (theoretical knowledge) and art (practical know-how), and had no exact Latin equivalent, gave his sphere a more utilitarian cast than Sacrobosco's original. Second, emphasis on the practical benefits of astronomy was a common feature of vernacular spheres, and indeed of vernacular scientific texts more generally. Finally, this case study illustrates the important role of printers in shaping texts. Cammerlander's decision to append a section on astrology to the last edition of Heinfogel's translation highlighted the utility of astronomical knowledge and its relevance to everyday life.

\section{Guillaume des Bordes' La sphere de Jean de Sacrobosco}

Our second example is a French translation of the Sphere by Guillaume des Bordes, a professor of mathematics. ${ }^{38}$ It was first published in 1570 , by the Parisian printers Guillaume Cavellat and Jérôme de Marnef, ${ }^{39}$ and it went through at least five more editions, the last in $1619 . .^{40}$ This translation was commissioned by the printers Cavellat and de Marnef, who sought to capitalize on the growing market for vernacular mathematical and astronomical books. The French translation of the Sphere combined the strengths and resources of both printing houses. Guillaume Cavellat was a libraire-juré - a printer affiliated with the University of Paris. He specialized in books for university students, especially in the areas of mathematics, astronomy and cosmology. ${ }^{41}$ One of these books was a Latin version of Sacrobosco's Sphere, the standard introductory astronomy text at Paris. Cavellat printed Latin editions of the Sphere in 1549, 1550, 1551 and 1552. In 1561, he switched to publishing the Sphaera emendata. ${ }^{42}$ This was a new and updated version of Sacrobosco's Sphere with annotations by the humanist scholar Elie Vinet $\left(1509\right.$ - 1587). ${ }^{43}$ Vinet's Sphaera emendata was widely used as a teaching text throughout Europe. One of the first universities to adopt it was the Lutheran University of Wittenberg. Printers in Wittenberg added a preface, written by Philip Melanchthon (1497 - 1560), extolling the value and utility of astronomical knowledge. ${ }^{44}$ This preface was widely reprinted in editions of the Sphere, even in Catholic countries, and Cavellat included it in his editions. Although Melanchthon's works were all placed on the Index of prohibited books in 1559, Catholic publishers like Cavellat continued to include this preface, although they frequently removed Melanchthon's name. ${ }^{45}$ Cavellat's editions of the Sphaera emendata were richly illustrated, with about fifty different woodcuts, including volvelles. ${ }^{46}$

The other half of this partnership was Jérôme de Marnef, member of a highly successful family of printers. Unlike Cavellat, who specialized in books aimed at the small but steady market of university faculty and students, the Marnef family printed a wide range of religious, literary and historical texts, many of them in the vernacular. The publishing partnership of Cavellat and de Marnef officially began in 1563, although Cavellat had married de Marnef's niece Denise four years earlier. ${ }^{47}$ Cavellat commissioned Guillaume des Bordes to produce a French translation of the Sphaera emendata that he had been printing for several years. Because he had des Bordes translate the same version of the Sphere that he had been printing in Latin (Elie Vinet's Sphaera emendata), Cavellat was able to reuse all the existing woodcuts to illustrate the French version, without having to 
create new ones. While Cavellat had experience and expertise printing mathematical books, de Marnef had experience and expertise selling books to a much broader reading public than Cavellat. The result of their collaboration was a book that was profitable to both. Indeed, it was so profitable that Cavellat largely stopped publishing university texts and turned to the more lucrative genres of French schoolbooks and religious works. ${ }^{48}$

While the careers of Cavellat and de Marnef are well documented, little is known about the translator. On the title page of his Sphere, he describes himself as "Guillaume des Bordes, Bordelais gentleman, licensed in law, professor of mathematics."49 Des Bordes had already worked with Cavellat on two astronomical books before he made the translation of the Sphaera emendata. Des Bordes worked as a consultant on a Latin edition of the German astronomer Johan Stöffler's treatise on the astrolabe in $1553,{ }^{50}$ and he wrote a preface to a French translation of the same work in $1560 .{ }^{51}$ In his dedicatory preface, des Bordes asserted that the Sphere was a valuable book that ought to be accessible to a larger audience. "Because out of all the books we have today [the Sphere] merits being seen, read, corrected against its true example and using that medium restituted in its entirety," he wrote, "I have tried to translate it and make it speak better in French." 52 Violaine Giacomotto-Charra argues that sixteenth-century French translators like des Bordes saw Latin as an obstacle preventing vernacular readers from understanding astronomy, an obstacle that they had a duty to remove. ${ }^{53}$ Des Bordes also declared that the Sphere was a book that should be widely read. He claimed that he undertook the translation project "so no one can excuse themselves from the study of these beautiful sciences, as they can when they are only written in Latin." 54 The argument that the Sphere is a vitally important text that ought to be broadly known and read is continued in the "Preface on the Utility of Astrology." This was actually Melanchthon's preface to the Sphere, retitled and without Melanchthon's name attached to it. In this preface, and des Bordes' translation, Melanchthon argues that human beings have a positive duty to study the stars because the magnificence of the heavens reveals the divine power and providence of God. ${ }^{55}$ Melanchthon intended this preface for university students, a tiny, elite, exclusively male audience. Translated into French, his words became an argument for the broad diffusion of astronomical knowledge in the vernacular. And by retitling the preface "On the Utility of Astrology," des Bordes emphasized the practical benefits of studying the heavens. Both the new title and the translation into French thus shifted the meaning of the preface.

Nearly every section of the French sphere has some sort of annotation, adapted from Elie Vinet's annotations in the Sphaera emendata. ${ }^{56}$ Some of the annotations update the information in Sacrobosco's text. Take, for instance, the annotation of the passage in which Sacrobosco claims that the coldest and warmest regions of the world are uninhabited:

In terms of the zones or belts that many have estimated to be uninhabitable due to great heat or cold, we have found and known by many and diverse navigations made in our time that there were men and women who lived in these regions....How many are there in the Portuguese [colonies] in the eastern torrid zone? How many will we find in other Spanish colonies in the same hot zone in the West? We know even less and are less familiar with the cold zones and regions than the hot. ${ }^{57}$ 
This particular annotation reflects the discoveries made by the Portuguese and Spanish voyages of exploration that began in the fifteenth century and took Europeans into parts of the globe - including southern Africa, the Caribbean and South America - where they had previously never been. The book also has a picture of a globe with a map of Africa that reflects the Portuguese exploration of the west coast and circumnavigation of that continent in the $1490 \mathrm{~s} .^{58}$

Although des Bordes claimed he was making Sacrobosco's text available to those who could not read Latin, the annotations are sprinkled with references to authors and texts available only in Latin. There were, for example, references to more recent work in astronomy, including that of Georg Peuerbach (1423 - 1461), Jacobus Faber Stapulensis (or Jacques Lefèvre d'Étaples, ca. 1450 - 1536), Francesco Capuano di Manfredonia (fl. ca. 1490), and Pedro Nunes (1502 - 1578). ${ }^{59}$ None of these authors' astronomical works was available in French translation. ${ }^{60}$ Further, many of the annotations contain Greek words and discussions of their meanings. One of these annotations even criticizes Sacrobosco's poor grasp of Greek: "Jean de Sacro Bosco shows in many places that he has little knowledge of the Greek language. . . ." 61 Des Bordes' French sphere thus retained many of the trappings of humanist erudition that characterized Elie Vinet's Sphaera emendata, the sphere Cavellat had printed several times already. But even those French readers who could not access the Latin works referred to in the annotations could gain some familiarity with recent developments in astronomy and cosmology from reading des Bordes' translation.

This French sphere was primarily the product of two enterprising printers, who commissioned the translator. They took advantage of the growing market for vernacular books, especially for vernacular books on scientific subjects. The fact that one of these printers, Cavellat, had been printing Elie Vinet's Sphaera emendata for several years meant that they had woodblocks for all the illustrations available that could simply be reused, thus lowering the initial costs of printing. Like many spheres, both in Latin and in the vernacular, des Bordes' French sphere contained extensive annotations that reported new discoveries about the cosmos and incorporated the work of more recent astronomers. Even though the text, annotations and preface were all closely based on Latin originals, they were subtly but significantly changed in the French translation to emphasize the utility, accessibility and value of astronomical knowledge for a broad readership.

\section{Piervincenzo Danti's La Sfera di Messer Giovanni Sacrobosco}

Our third example is an Italian translation that was made in 1498 by Piervincenzo Danti (ca. 1440 - 1512). He initially prepared the translation for his children, Teodora and Giulio. It remained in manuscript form until 1571, when Piervincenzo's grandson, Egnatio Danti (1536 - 1586), arranged for it to be printed. It went through three editions, two printed in Florence (1571 and 1579) and one in Perugia (1574). ${ }^{62}$ Piervincenzo did not just translate Sacrobosco's text; he added substantial annotations, and his grandson Egnatio may have added or modified some of these annotations before the book was 
printed. As in the French version discussed above, the annotations in this Italian version expand, clarify and update the information offered in the original text. In addition, the annotations in Piervincenzo's sphere contain several references to his native Perugia, which give the book a distinctively local flavor.

Relatively little is known about Piervincenzo Danti, except that he was from the Umbrian city of Perugia, and skilled in mathematics, astronomy and architecture. ${ }^{63}$ All three printed editions include a dedicatory letter, dated September 6, 1498, to Alfano Alfani (1465 - 1550), a prominent Perugian banker with close ties to the papacy (he served for forty years as papal treasurer in Umbria) ${ }^{64}$ It is not clear whether Piervincenzo presented a manuscript translation to Alfani or whether he intended the work to be printed. It is also not clear how much this dedication - or indeed the translation and annotations - were altered or composed at a later date by Egnatio Danti. In this dedicatory preface Piervincenzo describes how he retired with his family to his "little villa" (piccola villetta) during an outbreak of the plague. While enjoying the enforced "solitude and quiet" (solitudine \& quiete) of this retreat, he made numerous astronomical observations, and decided to teach his children the "noble art" (nobil' arte) of astronomy. For this purpose, he translated the Sphere of Sacrobosco into Italian. The child who showed the most aptitude for astronomy was his eldest daughter Teodora, who mastered not only the Sphere but a work on the astrolabe and an almanac as well. He describes this daughter as the one to whom "you gave the name of Teodora [while] holding her at her baptism" (cui voi imponeste il nome di Teodora tenendola al battesimo), implying that she was Alfani's godchild. ${ }^{65}$ Piervincenzo's dedication offers an example of the use of a sphere in the private tutoring of wealthy children. It also offers rare evidence of a female reader of a sphere.

Teodora Danti (c. 1498 - c. 1573) went on to become a well known artist, although she has since fallen into obscurity and there are no extant works attributed to her. The sole biographical information about her (except for the mention in her father's sphere translation) is an entry in Lione Pascoli's Vite de Pittori, Scultori, ed Architetti Perugini (Lives of Perugian Painters, Sculptors and Architects) (1732). ${ }^{66}$ Pascoli describes her as a painter, but also as highly learned in mathematics, philosophy and literature. According to Pascoli (who offers no citations), she wrote poetry, a commentary on Euclid and a treatise on painting. However, Pascoli gives Teodora's birthdate as 1498, the same year as the dedicatory preface. While Teodora may well have been precociously brilliant, it seems unlikely that she read astronomical works as an infant. It is possible that Egnatio added the reference to his aunt, who had achieved a certain fame, at least in Perugia, by the time this sphere was first printed in 1571. In his own dedicatory preface, Egnatio repeats his grandfather's story about translating the Sphere during a plague epidemic in 1498 for the instruction of his children, and notes the marvelous talents of his aunt Teodora. ${ }^{67}$

Egnatio Danti ${ }^{68}$ was the son of Piervincenzo's son Giulio Danti (1500 - 1575). Giulio, like his father and sister, was highly educated and particularly skilled in mathematics and art. He trained as an architect and goldsmith. ${ }^{69}$ Egnatio had two brothers, Vincenzo (1530 - 1576) and Girolamo (1547 - 1580), both of whom were artists. Egnatio studied mathematics, astronomy and cartography. Vincenzo became a sculptor at the court of Cosimo I de' Medici (1519 - 1574), and it is possible that he was the one who drew the Duke's 
attention to the talents of his younger brother. In 1562, Egnatio became a cosmographer to Cosimo I when the Duke asked him to prepare maps and a large terrestrial globe that still adorn the Sala delle Carte, or Map Room, of the Palazzo Vecchio in Florence. Egnatio wrote widely circulated works on how to make and use an astrolabe, as well as authoring works on other astronomical topics. Cosimo commissioned him to give public mathematical lectures and to study the reform of the calendar. As part of his study of calendar reform, Egnatio mounted astronomical instruments on the outer wall of the church of Santa Maria Novella in Florence, which he used to determine the precise date of the vernal equinox..$^{70}$ It was in this period that he arranged for the publication of his grandfather's translation of the Sphere.

Cosimo de Medici died in 1574 and his oldest son Francesco became the Grand Duke of Tuscany. The same year, the second edition of Piervincenzo's translation of the Sphere was published, this time with a dedication to Johanna of Austria, Francesco de' Medici's wife and the new Grand Duchess of Tuscany. This may have been Egnatio's attempt to secure patronage from the new Grand Duke and his wife. If so, it was singularly unsuccessful. In 1575 Francesco ordered Egnatio to leave Tuscany. ${ }^{71} \mathrm{He}$ became a professor of mathematics at the University of Bologna, and then gained the patronage of Pope Gregory XIII. He created maps of the papal states and served on the papal commission for calendar reform. The last edition of Piervincenzo's sphere was published in 1579, this time with a dedication to Giovanni de' Medici (1567 - 1621), the illegitimate son of Cosmio I de' Medici.

The printed version of Piervincenzo's sphere included new information about the heavens and the earth. For example, readers were informed that the declination of the zodiac (la declinatione del Zodiaco) had changed since the days of the ancient Greeks. The declination of the zodiac - or the obliquity of the ecliptic - is the angle between the axis of the celestial sphere's rotation and the axis of the sun's annual rotation. ${ }^{72}$ According to Ptolemy, this angle was decreasing at a very slow rate. Subsequent astronomers in the Islamic world argued that the value of the angle oscillated, being sometimes larger and sometimes smaller. The mathematician and astronomer Thabit ibn Qurra (ca. 836 - 901) devised mathematical models to account for this phenomenon, known as trepidation. ${ }^{73}$ Thabit's work was translated into Latin in the twelfth century by Gerard of Cremona (ca. 1114 - 1187), but it was not immediately accepted. In the Sphere, Sacrobosco used Ptolemy's model of linear change in the obliquity of the ecliptic rather than Thabit's model of oscillation. However, by the fifteenth century when Piervincenzo was making his translation, the phenomenon of trepidation was widely accepted among astronomers, and many Sphere commentators incorporated some discussion of it into their annotations. Piervincenzo states that, in Ptolemy's era, the declination of the zodiac was 23 degrees, 51 minutes, 20 seconds. At the time of Albategnius, ${ }^{74}$ around the year 880, it was 23 degrees, 55 minutes. At the time of Arzachel, ${ }^{75}$ around the year 1070, it was 23 degrees, 34 minutes, 40 seconds. At the time of Almeon Almansor, around the year 1140, it was 23 degrees, 33 minutes, 30 seconds. And finally, "in our time in the year 1497" (Ai nostri tempi che siamo nel anno 1497) the value is about 23 degrees, 29 minutes. ${ }^{76}$ These values support the idea that the obliquity of the ecliptic oscillated slowly over the centuries.

Readers were given new information on the terrestrial realm as well. After the section in which Sacrobosco claims that the torrid zone (the region around the equator) is too hot 
to support life, the following comment was added: "That the torrid zone, and the two frigid zones are uninhabitable, Christopher Columbus in the year 1491 showed us to be false," "77 because his voyage took him into lands within the torrid zone and he discovered that these lands did indeed have inhabitants. This annotation concludes with the following assertion: "I saw a copy of the letter Columbus wrote in Seville to the very learned and expert mathematician Master Paolo Toscanelli of Florence."78 The reference here is to Paolo Toscanelli Dal Pozzo (1397 - 1482), an astronomer, astrologer and geographer. ${ }^{79}$ This letter is almost certainly fictional. Columbus' first voyage was in 1492, one year after the letter was supposedly written and ten years after Toscanelli's death. Henry Vignaud surmised that the reference to the letter in this annotation was a later interpolation by Egnatio Danti. ${ }^{80}$ However, none of this alters our point that Piervincenzo - or possibly his grandson Egnatio - updated Sacrobosco's Sphere with new information.

The Perugian roots of Piervincenzo and Egnatio are reflected in their dedications to powerful Perugian patrons, and in several of the annotations as well. For example, at the end of the section "on the rotundity of the heavens" (della rotondita del cielo), Piervincenzo added the following geometrical example: "So, if there are two cities, and one of them is almost the shape of a pentagon, like Perugia, and the other is almost round like Florence, then [the area of] Florence will be much larger than [that of] Perugia, even though the length of the city walls is equal." 81 One can imagine Piervincenzo demonstrating this to his children, or asking them to work it out themselves. After the next chapter, "that the earth is round" (che la terra sia rotonda), he notes that, the more northerly a region is, "the more stars near that Pole never fade. This occurs near the Arctic Pole here at Perugia, where the constellations of Ursa Minor, the Dragon, Cepheus and Cassioppea never set, and some others, like Ursa Major and the Serpent remain partly above the horizon." 82 And finally, after the chapter on the five climactic zones, he notes that Perugia is "almost in the same latitude as Amaseia, the homeland of Strabo." 83

Like the French translator des Bordes, Piervincenzo Danti added numerous annotations to his sphere that clarified and corrected Sacrobosco's original text. It is highly likely that these annotations were further expanded and modified by Piervincenzo's grandson Egnatio before the sphere was printed. This Italian sphere was linked to three generations of the Danti family, whose members were known for an impressive array of accomplishments in painting, sculpture and architecture, as well as mathematics, astronomy and cartography. Indeed, the printed sphere, with its references to multiple family members - Piervincenzo, Teodora, Giulio and Egnatio - may well have been calculated to enhance the family's reputation.

\section{Thomas Hill's The Schoole of Skil}

Our final example of a vernacular sphere is Thomas Hill's The Schoole of Skil. This sphere was published in 1599, twenty-five years after Hill's death, by the London printer William Jaggard.$^{84}$ Unlike our previous three examples, it is not obvious from the title page of this English book that it is a sphere. The phrase "Of the sphere" is buried in its very long subtitle, and Sacrobosco's name is entirely absent. However, the text follows the basic structure and content of Sacrobosco's Sphere and contains illustrations similar to those in other spheres. The text is significantly longer than Sacrobosco's, and much 
additional explanatory material has been added. Unlike the French and Italian versions we have examined, this additional explanatory material has simply been incorporated into the text. No distinction is made between the original text of Sacrobosco and the commentary. Hill's sphere has a minor place in the history of astronomy because it contains a refutation of the Copernican heliocentric system, one of the earliest in English. However, the really distinctive feature of this sphere - as compared to other English spheres and continental exemplars - is its greatly expanded sections on geography. Hill's discussion of heliocentrism takes up approximately four pages ${ }^{85} \mathrm{By}$ contrast, geographical topics occupy nearly a quarter of the book.

Thomas Hill (ca. 1528 - ca. 1574) was a prolific and well-known writer. ${ }^{86} \mathrm{He}$ published books on a range of subjects including physiognomy, the interpretation of dreams, Paracelsian medicine and gardening. He produced at least nine almanacs and a collection of recipes. Many of his works, such as his treatise on gardening ${ }^{87}$ went through multiple editions and stayed in print long after his death. In addition to the works that appeared in print, Hill left a number of unpublished manuscripts when he died. The Schoole of Skil was one of these unpublished manuscripts.

Hill was prolific, but he was not particularly original. Many of his works were translations and compilations of other books. In her 2005 dissertation, Katherine Tredwell demonstrated that Hill's Schoole of Skil was largely composed of translated excerpts from Caspar Peucer's (1525 - 1602) Elementa doctrinae de circulis coelestibus et primo motu (1551). ${ }^{88}$ Peucer's Elementa doctrinae, in turn, contains passages lifted directly from Philip Melanchthon's (1497 - 1560) Initia doctrinae physicae (1549). In particular, the passages refuting heliocentrism are taken almost verbatim from Melanchthon. ${ }^{89}$ This English sphere, like the French sphere we discussed above, provides further evidence for the wide influence of the Lutheran educator Philip Melanchthon on astronomical and mathematical texts. Tredwell suggested, although she was not able to verify, that some of the geographical material that was not in Peucer's Elementa doctrinae might have been taken from one of Peucer's geographical works. We have been able to confirm that a significant amount of the geographical material was indeed taken from Peucer's $D e$ dimensione terrae (On the size of the earth).${ }^{90}$ For example, one of Hill's descriptions of America is a slightly shortened version of Peucer's:

America in the sea Atlanticus, is of such greatness, that the same is supposed to be a fourth part of the world inhabited: the middle or halfe of it hath the longitude of 330. degrees, and the latitude of tenne degrees Southward. The sea Altanticus [sic] hath many large Ilands in it; among which, the most notable are Spagnolla, Cuba, Parias (otherwise Chersonesus) by the straight that reacheth upward into the north. The middle of the same hath the longitude of 285 . degrees: the latitude Northerly 44. degrees. For from 11. unto 50. almost it reacheth unto. America streacheth far into the South, beyond the tropic of Capricorne, although his bounde or furthest part Southerly bee not yet founde or knowne. ${ }^{91}$

We will discuss other passages that Hill borrowed from Peucer later in this section.

The London printer William Jaggard (ca. 1568 - 1623) acquired the manuscript of Hill's Schoole of Skil and printed it in 1599. Jaggard is most famous today for publishing Shakespeare's first folio..$^{92} \mathrm{He}$ was a very successful printer who published a wide array of books and pamphlets. In 1604, he acquired a royal monopoly to print copies of the Ten 
Commandments, which all parish churches were required to post. He became the official printer for the City of London in 1610. Other scientific works printed by Jaggard include Edward Topsell's The Historie of the foure-footed Beastes in 1607 and The Historie of Serpents in 1608, and the 1602, 1612, and 1613 editions of Francis Bacon's Essays.

The title of the work, The Schoole of Skil, appears to have been chosen by Jaggard, who notes in his preface "To the Reader" that the manuscript that came into his hands after Hill's death was titled "The Rudiments of the Sphere." 93 According to the Oxford English Dictionary, in sixteenth- and seventeenth-century English the word "skill" meant "practical knowledge in combination with ability." Skill was equated with "the ability to perform a function, acquired or learnt with practice." It was in this sense that John Dee $(1527-1609)$ used the word in his famous preface to the first English edition of Euclid: "Of the former knowledge Geometricall, are growen the Skills of Geographie, Chorographie, Hydrographie, and Stratarithmetrie."94 The title was undoubtedly calculated to appeal to the market for vernacular mathematical books in early modern London. Deborah Harkness has described this market, and noted that authors of mathematical books attempted to appeal to readers "by promoting the notion that mathematical and instrumental literacy fostered inventiveness, cunning, and quick problem solving." 95 In his preface "To the Reader," Jaggard declared that the book contained material "whereof there is use both on Sea and Lande."96 Throughout the Schoole of Skil, Hill himself emphasized the practical utility of cosmological knowledge. The phrases "uses of" and "utility of" are repeated frequently throughout the text. Hill pointed out specific practical uses of cosmological knowledge: weather prediction, ${ }^{97}$ navigation, ${ }^{98}$ astrology, ${ }^{99}$ instrument making, ${ }^{100}$ and medicine. For example, on this last he writes, "Avicen thus writing of the Dog-daies, willeth men to beware, and learne the time in which the greater Dog [star] ariseth . . . for then is no apt time of ministring medicine."101

The most prominent additions Hill made to Sacrobosco's text were in geography. Sacrobosco covered geographical subjects in the Sphere, including the dimensions of the earth, the percentage of the earth covered by water and the different climate zones. In Hill's Schoole of Skil, these sections are considerably augmented with data from fifteenth- and sixteenth-century voyages of exploration, as well as with commentary drawn from ancient, medieval and contemporary writers. Like des Bordes and Danti, Hill refuted Sacrobosco's claim that the torrid zone was uninhabitable:

the Spaniards and Portingals [have shown that] ... the places under the Equinoctiall, and the rich City Calecute, being by the sea coast of Inde, standing betweene the equatour and our Tropicke of Cancer, and unto the other Tropicke South under the burning zone, . . is habitable and peopled, although very cumbersome with extremity of heat. ${ }^{102}$

Hill also describes the purported characteristics of the people living in this region of the globe. Although the so-called "burning zone" was habitable, it produced people who were, "monstrous of forme, and have rude wits, . . . like to wilde and furious beasts." People who lived near the equator, including "Ethiopians or Moores," had small heads because their brains were "but litle and withered." They had short, crooked, black bodies, "wrinckled faces," and "thicke crisped haire on their heades," and they were "grosse and dull of senses." 103 As for the frigid regions under the north and south poles (the arctic and antarctic circles), Hill reports that "it is well knowne that Gothland, Norway, Russia, 
Lapeland, Groneland, and divers other countries towarde the North pole, is inhabited and well peopled." 104 The people of these cold regions were superior to the people of the hot regions. They were "white of body, having long heare on the head, tall and comely of stature and personage." 105 However, the great cold of these regions made them "wilde and cruell." The people of the temperate zones, which included most of Europe, were "gentler and civiler" and "temperate in nature and quality."106

Hill explains that knowledge of the latitudes and longitudes of various cities can enable one to calculate the distances between these cities. In these sections, he draws most of his material from Peucer's On the size of the earth. For example, Hill writes:

If two places offered or given be placed under the Equatour, of which the space is sought, then the arke of the difference of latitude, is the same with the arke of the distance, neither doth the verticiall cyrcle differ from the Equatour. For the equator of either place doeth containe the verticiall points, as may appeare in this triangle, noted with. A. B. C. [There is an accompanying diagram, which is the same as the one in Peucer's De dimensione terrae (1553), p. 108] Of which, if 15. germain miles be wrought into parts of the difference of longitude, and any scruples after remaine, devide those by 4 . For (by so many minutes of a degree, doth a Germain mile answere) that the distance shall make. As Ptholomie writeth, of the places under the Equatour. ${ }^{107}$

Hill also explains, again in passages drawn from Peucer, how to calculate the distances between cities that differ only in longitude, cities that differ only in latitude, and cities that differ in both longitude and latitude. He gives numerous examples to teach the reader how to make each of these types of calculations. Many, although not all, of these worked examples are taken from Peucer. One of the examples that comes out of Peucer is a calculation of the distance between Gdansk and Lübeck:

The longitude of Danske is of 39. degrees, and two scruples or minutes: the latitude of the same hath 54. degrees, and 48. minutes. The longitude of Lubecke is of 28. degrees, and 20 scruples, the latitude hath 54. degrees, and 48. scruples. The difference of longitude consisteth, of 10 . degrees, and 42. minutes. The halfe difference is, of 5. degrees, and 21. scruples. The distance on earth, betweene Danske and Lubecke, is of 92 Germaine miles, and a halfe. ${ }^{108}$

Many of the worked examples were drawn from Peucer, but not all. In fact, Hill's Schoole of Skil has many more examples of calculations of the distances between cities than Peucer's On the size of the earth. One such example was the distance between Trent and Wittenberg:

The longitude of Trydent [Trent] is of 30. degrees, and 30. minutes. The longitude of Viteberge [Wittenberg] is asmuch. The latitude of Trydent is of 45 . degrees, and 14. minutes. The latitude of Viteberge is of 51. degrees, and 50. minutes. These now differ in onlely the latitude, which difference of the latitude is of 6. degrees, and 36. minutes; that is, 99. Germaine miles. So much is the distance almost between Trydent and Viteberge. ${ }^{109}$

This was highly charged pairing. Hill calculated the distance between Trent, site of the Council of Trent (1545 - 1563), where the Catholic Counter-Reformation began, and Wittenberg, center of the Lutheran Reformation. The geographical distance between 
these cities may have been ninety-nine German miles, but the theological distance was infinitely greater. Hill made other modifications for his English readers. Most of the distances between cities are given in German miles, and Hill included a conversion: four German miles were approximately equal to twenty-two English miles. ${ }^{110}$ Further, Hill gave three worked examples of distances between pairs of English cities: York and Berwick, London and Northampton, and Colchester and Oxford. These distances are given in English miles, and these examples are not in Peucer's book. ${ }^{111}$

Of the four spheres we have examined, this English example is the most changed from Sacrobosco's original text. Like the French sphere, it is heavily based on Latin books, but Hill transformed two texts of Peucer in significant ways, rearranging the material and combining it in new ways for his English readers. Hill and Jaggard both emphasized the utility of cosmological knowledge, in the title, the preface and the text itself. Hill gave special prominence to geographic knowledge and its applications. His series of worked examples of the distances between different cities constituted a set of lessons in spherical geometry that readers might well have applied to other subjects.

$$
* * *
$$

These four examples suggest that the Sphere played a greater role in European intellectual life than has hitherto been recognized. The Sphere was widely read, in Latin and in multiple European vernaculars, especially in the age of print. It was not confined to a small elite of university students, but broadly disseminated. This was especially true of vernacular editions, which were accessible to those who could read their native tongue, but not necessarily Latin. The numerous sphere translations were part of a dramatic expansion in scientific literature in various European languages in the sixteenth century. Both translators and printers played crucial roles in the production and dissemination of scientific texts in the vernacular. Translators might be interested in making astronomical information available to a broader audience (like Heinfogel and des Bordes), or they might be interested in enhancing their own and their family's reputation (like the Dantis), or they might be men who wrote for a living (like Hill). Printers made key choices about what to print and in what format. Their decisions were motivated primarily by economic considerations. If they were to be successful (and indeed if they were to remain financially solvent), printers had to be shrewd judges of the book market. Many printers throughout Europe found translations of the Sphere to be a sensible and worthwhile investment, and they sought to make their editions as attractive as possible to potential buyers. For different reasons then, translators and printers worked to make the Sphere appealing and accessible to a broad audience. They added material to bring the text upto-date, correcting both astronomical and geographical information. One of the main ways that a sixteenth-century person could learn about voyages of exploration or astronomical discoveries was by reading a sphere. At the same time, translators and printers promised their readers that their spheres offered not just interesting information, but useful knowledge that might be turned to practical benefit. Vernacular spheres offer a unique window into the meanings and uses of astronomical knowledge for diverse groups of readers. 


\section{Acknowledgements}

It is our pleasure to thank the many individuals who assisted us during our research and writing. First and foremost, Peter Barker read several drafts of this article. He and two anonymous readers for the $J H A$ helped us both sharpen our arguments and avoid several errors. Kerry Magruder and JoAnn Palmieri made the resources of the University of Oklahoma's History of Science Collections available to us. Sarah Werner and Jane Wickersham shared their expertise in (respectively) sixteenth-century English and sixteenth-century Italian history and culture and supplied us with many useful references. Peter Barker, Sylvia Venable and Jane Wickersham helped with the translations. James Burnes contributed to our earliest conversations about this project and helped shape its final form.

\section{Notes on Contributors}

Kathleen Crowther is an Associate Professor of the History of Science at the University of Oklahoma. Her first book, Adam and Eve in the Protestant Reformation (Cambridge, 2010) won the Gerald Strauss Prize for best new book in Reformation studies. She is currently working on a book about Sacrobosco's Sphere.

Ashley McCray studies indigenous knowledge as a PhD student in the University of Oklahoma's History of Science program. She defended her master's thesis, 'Money, Science, and Politics: The Patronage of Harriet Martineau's Political Economy' in 2014. She is currently a Graduate Student Research Fellow for OU's Center for Social Justice.

Leila McNeill is an educator for primary prevention of sexual assault and domestic violence in Texas. She also is a freelance science history writer with an upcoming publication about women science popularizers of the nineteenth century.

Amy Rodgers is a PhD student in the History of Science at the University of Oklahoma, with research specialties in medicine and literature in 19th and 20th century Britain and America. She is currently the editorial assistant for Technology and Culture and also works as a freelance editor.

Blair Stein is a doctoral student in the History of Science at the University of Oklahoma. Her current research examines climate, identity, and technological innovation in 20th century Canada. Her work has appeared in Technology and Culture and the Journal of Religion and Culture.

\section{Notes}

1. For modern translations, see Lynn Thorndike, The Sphere of Sacrobosco and its commentators (Chicago: University of Chicago Press, 1949) and Sacrobosco, Sphaera in Edward Grant (ed.), A source book in medieval science (Cambridge MA: Harvard University Press, 1974), 442-451.

2. We have used the on-line bibliography compiled by Roberto de Andrade Martins of the Group of History and Theory of Science, University of Campinas (Unicamp), Brazil. http:// ghtc.ifi.unicamp.br/Sacrobosco/Sacrobosco-ed.htm. We know of no comparable bibliography of manuscript editions. See also Jürgen Hamel, "Johannes de Sacroboscos Handbuch der Astronomie (um 1230) - kommentierte Bibliographie eines Erfolgwerkes," in Dietmar Fürst and Eckehard Rothenberg (eds.), Wege der Erkenntnis: Festschrift für Dieter B. Herrmann zum 65. Geburtstag (Frankfurt am Main: Harri Deutsch, 2004), 115-170 and 
Hamel, Studien zur "Sphaera” des Johannes de Sacrobosco (Leipzig: AVA, Akademische Verlagsanstalt, 2014).

3. We base this estimate on the number of vernacular editions in Roberto de Andrade Martins's on-line bibliography (ref. 2). However, this bibliography does not include English translations of the Sphere and may miss some other editions as well.

4. Our title alludes to Owen Gingerich's ironic description of Copernicus' De revolutionibus (1543). See Owen Gingerich, The book nobody read: chasing the revolutions of Nicolaus Copernicus (New York: Walker \& Co, 2004).

5. Thorndike, The Sphere of Sacrobosco (ref. 1); Olaf Pedersen, "The Corpus Astronomicum and the Traditions of Medieval Latin Astronomy" Studia Copernicana xiii (1995), 57-96; Pedersen, "In quest of Sacrobosco" Journal for the history of astronomy xvi (1985), 175221; and Owen Gingerich, "Sacrobosco as a textbook" Journal for the history of astronomy xix (1988), 269-273.

6. James Lattis's study of the Jesuit Christopher Clavius's commentary on Sacrobosco's Sphere illustrates how the Sphere was used to introduce new ideas and information about the cosmos. See James M. Lattis, Between Copernicus and Galileo: Christoph Clavius and the collapse of Ptolemaic cosmology (Chicago: University of Chicago Press, 1994). We provide further examples below.

7. The history of the book has a voluminous literature. We have found the following books particularly useful: Andrew Pettegree, The book in the renaissance (New Haven: Yale University Press, 2010); David Finkelstein and Alistair McCleery, An introduction to book history, 2nd ed. (New York: Routledge, 2013); and David McKitterick, Print, manuscript and the search for order, 1450 - 1830 (Cambridge: Cambridge University Press, 2003).

8. See http://ghtc.ifi.unicamp.br/Sacrobosco/Sacrobosco-ed.htm (ref. 2).

9. Pettegree, The book in the renaissance (ref. 7), 69.

10. On rising literacy rates, see Rolf Engelsing, Analphabetentum und Lektüre: Zur Sozialgeschichte des Lesens in Deutschland zwischen feudaler und industrieller Gesellschaft (Stuttgart: Metzler, 1973).

11. We use the masculine and feminine deliberately. Not all printers or readers were men, a point we document in this essay.

12. Henri Van Hoof, Histoire de la traduction en Occident (Paris: Duculot, 1991), 42.

13. Violaine Giacomotto-Charra, "Entre traduction et vulgarization: 1'astronomie en Français au XVIe siècle," in Traduire la science hier et ajourd'hui, ed. Pascal Duris (Pessac: Maiso des sciences de l'homme d'Aquitaine, 2008), 45-67, p. 46.

14. Isabelle Pantin, La poésie du ciel en France dans la seconde moitié du seizième siècle (Geneva: Droz, 1995), 31.

15. Miriam U. Chrisman, Lay Culture, Learned Culture: Books and Social Change in Strasbourg, 1480 - 1599 (New Haven, Yale University Press, 1982). See also Kathleen Crowther-Heyck, "Wonderful secrets of nature: natural knowledge and religious piety in Reformation Germany" Isis xciv (2003), 253-273.

16. Deborah E. Harkness, The jewel house: Elizabethan London and the Scientific Revolution (New Haven: Yale University Press, 2007), 97-141. See also Adrian Johns, The nature of the book: print and knowledge in the making (Chicago: University of Chicago Press, 1998) and Francis R. Johnson, Astronomical thought in Renaissance England: a study of English scientific writings from 1500 to 1645 (Baltimore: John Hopkins Press, 1937).

17. Conrad Heinfogel, Sphera materialis (Nuremberg: Jobst Gutknecht, 1516); Conrad Heinfogel, Sphera materialis (Cologne: Arnt von Aych, 1519); Conrad Heinfogel, Sphaera materialis (Strasbourg: Jacob Cammerlander, 1533); and Conrad Heinfogel, Sphaera Mundi (Strasbourg: Jacob Cammerlander, 1539). We have consulted all four editions in the British 
Library, and the 1533 edition at the University of Oklahoma. There is a transcription of the 1516 edition in Hamel, Studien zur "Sphaera" (ref. 2), 151-99.

18. There were two Portuguese sphaeras printed in 1510, but we have not been able to consult these. Tractado da Spera do mundo tyrada de latim em liguoagem

(Lisboa: Herman de Campos, ca. 1510) and Tractado da Spera do mu[n]do ti[m]rada de latim em lingoage [m] portugues (Lisboa: Germam Galbard, ca. 1510). There were at least three Portuguese and nine Spanish editions of the Sphere in the sixteenth and seventeenth centuries. Many of these translations included practical applications of astronomical knowledge for navigators as well as information gained by Europeans from voyages of exploration and colonization. These Iberian spheres will be the subject of a future article. For the current literature on these translations, see María M. Portuondo, Secret science: Spanish cosmography and the New World (Chicago: University of Chicago Press, 2009), chapter 1; Antonio Barrera-Osorio, Experiencing nature: The Spanish American empire and the early Scientific Revolution (Austin: University of Texas Press, 2006), 116, 131; and Antonio Hurtado Torres, "La 'Esphera' de Sacrobosco en la España de los siglos XVI y XVII: Difusión bibliográfica” Cuadernos Bibliográficos xliv (1982), 50-51.

19. The first and the most well known of these was the Deutsche Sphaera (German Sphere), by Konrad von Megenberg (1309 - 1374). See Jean-Paul Deschler, Die astronomische Terminologie Konrads von Megenberg: ein Beitrag zur mittelalterlichen Fachprosa (Bern: H. Lang, 1977) and Francis B. Brévart, Die deutsche Sphaera (Tübingen: M. Niemeyer, 1980). The second was the Puchlein von der Spera (Booklet on the Sphere) by an anonymous translator. For facsimiles and analysis of two German manuscripts of this translation, see Brévart (ed.), Johannes von Sacrobosco Das Puechlein von der Spera: Abbildung der gesamten Überlieferung, kritische Edition, Glossar (Göppingen: Kummerle, 1979).

20. For biographical information see Francis B. Brévart, Konrad Heinfogel: Sphera Materialis Text und Kommentar (Göppingen: Kummerle, 1981), 2-4. It is not clear when Heinfogel gained this appointment, but in the 1516 edition of Sphera materialis, he describes himself as "Magistri Conradts Heinfogels von Nuremberg. K. M. [Kaiserliche Majestät] Capellan.” Sig. Aii.

21. Bernhard Ebneth, "Sebastian II. Sperantius," in Neue Deutsche Biographie 24 (2010), 107-8.

22. Hermann Arthur Lier, "Ulsenius, Theoderich," in Allgemeine Deutsche Biographie 39 (1895), 270-1.

23. Jörn Günther, Passion of collecting: a selection of illuminated manuscripts, miniatures, and early printed books (Hamburg: Jörn Günther Antiquariat, 2009), 18.

24. Daniel Crouch and Nick Trimming, Catalogue IV: a selection from stock (London: Daniel Crouch Rare Books, 2009), 6 and 8.

25. In hoc opere haec co[n] tinentur noua translatio primi libri Geographiae Cl. Ptolomaei: quae quidem translatio verbum: habet e verbo fideliter expressum (Nuremberg: Johannes Stuchs, 1514).

26. "Nym ein Astrolabium / zu theütsch heysset es ein sternenlebs wann als der mundt und die lebssen sagen was in dem hertzen verborgen ist / Also das sternenlebs / der sternen heymligkeyt offenbart.” Heinfogel, Sphera materialis (1516), sig. Avii verso (ref. 17). Unless otherwise noted, all translations are our own.

27. "Das hab ich den zu lieb gethan / Die kein latein gelernet han / Und doch des büchleins kunst begeren" Heinfogel, Sphera materialis (1516), unpag., just before colophon (ref. 17). This passage is also found at the end of the 1519 edition, but not in the 1533 or 1539 editions. 
28. See the definition in Jacob and Wilhelm Grimm, Deutsches Wörterbuch, where Kunst is translated by the Latin words scientia and ars. Deutsches Wörterbuch von Jacob und Wilhelm Grimm (Leipzig, 1854-1961). Available on-line at http://woerterbuchnetz.de/.

29. Heinfogel, Sphera materialis (1516), sig. Aii (ref. 17).

30. Heinfogel, Sphera materialis (1516), sig. Aii (ref. 17).

31. Heinz Zirnbauer, "Gutknecht, Jobst” in Neue Deutsche Biographie 7 (1966), 346.

32. Josef Benzing, "Aich, Arnd" in Neue Deutsche Biographie 1 (1953), 114.

33. Josef Benzing, "Zum Leben und Werk des Strassburger Druckers Jakob Cammerlander," in Festschrift für Claus Nissen (Wiesbaden: Pressler, 1973), 26; Chrisman, Lay culture, learned culture (ref. 15), 52; and William Eamon, Science and the secrets of nature: books of secrets in medieval and early modern culture (Princeton: Princeton University Press, 1994), 108.

34. Chrisman, Lay culture, learned culture (ref. 15), 182.

35. "Junckfraw . . . ist kalt und trucken . . . herscht uber melancholei / die trucken und kalte irdische complexion ... Die junckfraw hat am menschen den bauch nabel dz ingewaid / und magen boden." Heinfogel, Sphaera Mundi (1539), sig. Iii (ref. 17).

36. "Mercurius ... ist kalt und feucht ... Bezeichner irrdischer ding / erkantnuß höflicher künst / als Rhetorica / Geometria / Philosophia. . . ." Heinfogel, Sphaera Mundi (1539), sig. Kii verso (ref. 17).

37. "Im Mertzen laufft die Sonn in wider / so keimt das erdtrich / die wurtzeln / beum und bletter grünet / die brünnen und wasser bewegen sich / und die lewt seint dann waidenlicher zu unkeuschen / dann zu der zeit wechste die feuchtigkeit deß blüts” Heinfogel, Sphaera Mundi (1539), sig. K verso (ref. 17).

38. There is very little biographical information on Guillaume des Bordes. He describes himself on the title page of his translation of the Sphere as a "professor of mathematics," and we presume, because of his ties to Cavellat, that he was affiliated with the University of Paris. See M. Hoefer, Nouvelle biographie générale depuis les temps les plus reculés jusqu'a nos jours, avec les renseignements bibliographiques et l'indication des sources a consulter: Vol. 13 (Paris: Firmin Didot, 1852), 752.

39. Guillaume Des Bordes, La sphere de Iean de Sacrobosco augmentée de nouveaux commentaires, \& figures grandement servant pour l'intelligence d'icelle (Paris: de Marnef \& Cavellat, 1570).

40. Cavellat and Marnef together published editions in 1570 and 1576. Guillaume Cavellat died in 1576 or 1577, and his widow Denise took over the business. In 1584, Cavellat and Marnef published a third edition of the French Sphere, but this time the "Cavellat" was Denise, not Guillaume. Denise Cavellat published two editions of the French Sphere on her own in 1607 and 1616. Another Parisian printer, Jacques Quesnel, published a final edition in 1619. Publication information is based in part on catalog searches, as we have not had access to all six editions. We have consulted digitized versions of the 1570, 1576 and 1619 editions in the database Early European Books Online.

41. Philippe Renouard, Imprimeurs et libraires parisiens du XVIe siècle: fascicule Cavellat/Marnef \& Cavellat. (Paris: Bibliothèque Nationale, 1986), 1. At least half of those, according to Renouard, could be labeled as "mathematics," which included astronomy, cosmology, and similar disciplines. (p. 5) On Cavellat's importance as a printer of mathematical and scientific texts, see Isabelle Pantin, "Les problèmes de l'édition des livres scientifiques: l'exemple de Guillaume Cavellat," in Le livre dans l'Europe de la Renaissance ed. Pierre Aquilon and Henri-Jean Martin (Paris: Promodis, 1988), 240-252 and François Loget, "De l'algèbre comme art à l'algèbre pour l'enseignement" Revue de synthèse cxxxii (2011), 495-527, 497. 
42. Renouard identifies ten different Sphere editions published by Cavellat between 1549 and his alliance with de Marnef in 1563; at least seven more follow. Renouard, Imprimeurs et libraires parisiens (ref. 41), 511.

43. For biographical information on Vinet, see Louis Desgraves, Elie Vinet, humaniste de Bordeaux (1509-1587): Vie, bibliographie, correspondence, bibliotheque (Geneva: Droz, 1977). On Cavellat's adoption of the Sphere, see Isabelle Pantin, "Teaching mathematics and astronomy in France: The Collège Royal (1550-1650)," Science and education xv (2006), 189-207, 194; and Renouard, Imprimeurs et libraires parisiens (ref. 41), 31.

44. For an English translation of this highly influential preface, see Philip Melanchthon, "Preface to On the Sphere (1531)" in Orations on philosophy and education, ed. S. Kusukawa, trans. C. Salazar (Cambridge: Cambridge University Press, 1999), 105-112.

45. On the widespread use of Melanchthon's preface, see Gingerich, "Sacrobosco as a textbook" (ref. 5). Nearly every Cavellat edition of the Sphere, regardless of language, had some version of this preface without concealing its Protestant origins until around 1560, after which it was printed anonymously. See Isabelle Pantin, "Teaching mathematics and astronomy in France" (ref. 43), 194.

46. The same woodcuts are also used repeatedly starting around 1550. Renouard, Imprimeurs et libraires parisiens (ref. 41), 100.

47. The original contract has been lost, but its terms were recorded on an updated contract following Guillaume Cavellat's death in 1576. Renouard, Imprimeurs et libraires parisiens (ref. 41), 162. Using marriages to unify publishing houses was a common feature of the European print world. See Johns, The nature of the book (ref. 16), 76-8; and Susan Broomhall, Women and the book trade in sixteenth-century France (Burlington, VT: Ashgate, 2002), 51-63.

48. For example, Cavellat independently and in partnership with de Marnef published multiple editions of a vernacular work on geometry: Jean Bullant and Henri Montmorency, Petit traicté de Géometrie et d'Horologiographie pratique (Paris: Chez Guillaume Cauellat, 1564).

49. des Bordes, La sphere, sig. A i (ref. 39).

50. Johann Stöffler, Elucidatio fabricae ususque astrolabii (Lutetiae: Apud Gulielmum Cauellat, 1533). Des Bordes helped Cavellat condense complicated figures for Stöffler's treatise on the astrolabe in 1553, and continued to contribute in a similar capacity until the 1570s. Renouard, Imprimeurs et libraires parisiens, p. 64 (ref. 41).

51. Johann Stöffler, Traité de la composition et fabrique de l'astrolabe, \& de son vsage: auec les precepts des mesures geometriques [trans. Jean Pierre des Mesmes] (Paris: chez Guillaume Cauellat, 1560).

52. "Et pource que entre tous les livres que nous ayons auiourdhuy, cestuy cy merite d'estre veu, leu, corrigé a son vray exemplaire, \& par ce moyen restitué en son entier, ie me suys essayé de le traduire \& le faire mieulx parler francois. ...” Des Bordes, La sphere (1570), sig. Aii (ref. 39). Giacomotto-Charra analyzes the differences between des Bordes's translation and the only earlier French version, translated in 1546 by Martin Perer. She notes that Perer's translation was "largely too close to the Latin text." Des Bordes's new translation was meant to be a more elegant one. Giacomotto-Charra, "Entre traduction et vulgarization" (ref. 13), 61.

53. Giacomotto-Charra, "Entre traduction et vulgarization" (ref. 13), 50.

54. 'qu'aucun ne se puisse excuser de l'estude de tant belles sciences, come font quand sont seu lemét escriptes en Latin" des Bordes, La sphere, Aii verso (ref. 39).

55. As an example of how this works in the text, consider one of the annotations to the section on the rotundity of the heavens: "And as God is without beginning and end, it is to be assumed that in creating the heavens He gave them a round shape, because this is the figure in which you can recognize neither the beginning nor the end." ( "Et d'autant que Dieu est 
sans commencement $\&$ fin il est a presupposer que creant les cieulx il leur a donne forme ronde qui est figure en laquelle on ne peult cognoistre le commencement ny la fin." Des Bordes, La sphere, fol. 15v [ref. 39]).

56. Philippe Renouard calls des Bordes' Sphere annotations “abridged” from Vinet's. Renouard, Imprimeurs et libraires parisiens (ref. 41), 222.

57. "Car les zones ou Ceinctures que beaucoup ont estimé estre inhabitables par la trop grand chaleur, ou froydeur, on a trouvé \& congneu par plusieurs et diverses navigations faictes de nostre temps, qu'il y avoit des hommes et femmes qui vivoyent esdictes regions. . . . Car combien y a il de Portugaloys, en l'orientale zone $\&$ region torride? Combien außi trouvera on de Colonies d'aultres Espagnolz soubz la mesme zone brulante vers Occident? Les zones $\&$ regions froydes ne nous sont poinct si bien congneuz ny si familieres que les chauldes." des Bordes, La sphere, fol. 32 (ref. 39).

58. des Bordes, La sphere, fol. 51v (ref. 39).

59. References to Peuerbach on fols. $10 \mathrm{v}$ and $13 \mathrm{v}$, Faber Stapulenis on fol. $13 \mathrm{v}$ and $43 \mathrm{v}$, Capuano on fol. $43 \mathrm{v}$, Nunes on fols. $15 \mathrm{v}, 18 \mathrm{v}, 37$.

60. However, Faber Stapulensis translated the Bible into French: La saincte Bible en francoys [trans. Jacques Lefèvre d'Étaples] (Antwerp: Martin Lempereur, 1530).

61. "Iean de Sacro Bosco monstre en plusieurs lieux qu'il est peu sçavant en la langue Greque ...” des Bordes, La sphere, fol. 34v (ref. 39).

62. Piervincenzo Danti, La Sfera di Messer Giovanni Sacrobosco (Fiorenza: Nella Stamperia de Giunti, 1571); Danti, La sfera Di M. Giovanni di Sacrobosco (Perugia: Nella Stamperia di Gio. Ber[n]ardino Rastelli, 1574); and Danti, La sfera di messer Giovanni Sacrobosco (Firenze: Nella stamperia de' Guinti, 1579). We have consulted all three editions at the University of Oklahoma, and a digitized version of the 1571 edition available on Google Books. There is some confusion over the dating of the first edition. The date on the title page is 1571 , while the date on the colophon is 1572 . There are listings for editions of both 1571 and 1572 in on-line databases like WorldCat, but we believe these are actually the same. Unless otherwise noted, all quotes are from the 1571 edition.

63. See the entry on Piervincenzo Danti by Francesco Paolo Fiore in the Dizionario biografico degli Italiani. (http://www.treccani.it/enciclopedia/piervincenzo-danti_\%28Dizionario_ Biografico\%29/) See also Lione Pascoli, Vite de pittori, scultori, ed architetti Perugini (Rome, 1732), 23-5.

64. See the entry on Alfano Alfani by Aldo Stella in the Dizionario biografico degli Italiani. (http://www.treccani.it/enciclopedia/alfano-alfani_\%28Dizionario_Biografico\%29/) All three printed editions include the original dedication to Alfani.

65. Danti, La Sfera (1571), all quotes on fol. 4 (ref. 62).

66. Pascoli, Vite de pittori (ref. 63), 75-9. She is the only female artist in Pascoli's book. This entry has been translated in Julia K. Dabbs (ed.), Life stories of women artists, 1550-1800: an anthology (Burlington, VT: Ashgate, 2009), pp. 209-12, with introductory material by Dabbs on pp. 205-8. Some on-line sources on Egnatio Danti include information on his aunt Teodora, but the information seems to derive ultimately from Pascoli's book (although it is not cited). See, for example, http://en.wikipedia.org/wiki/Ignazio_Danti and http://wwwhistory.mcs.st-andrews.ac.uk/Biographies/Danti.html.

67. It is also possible that Pascoli's dates are wrong. Egnatio's dedication is to Diomede della Corgna (1547-1596), the Marchese di Castiglione, a Perugian nobleman. In addition to his aunt, Egnatio mentions his father Giulio in this preface.

68. Biographical information from Francesco Paolo Fiore, "Danti, Egnazio (al secolo Carlo Pellegrino)" in Dizionario biografico degli Italiani (http://www.treccani.it/enciclopedia/ egnazio-danti_\%28Dizionario-Biografico\%29/); and Maria Luisa Righini-Bonelli, “Danti, 
Egnatio (Pellegrino Rainaldi)" in Complete dictionary of scientific biography, Vol. 3 (Detroit: Charles Scribner's Sons, 2008), 558-9.

69. See Francesco Paolo Fiore, "Danti, Giulio" in Dizionario biografico degli Italiani (http:// www.treccani.it/enciclopedia/giulio-danti_\%28Dizionario-Biografico\%29/).

70. J. L. Heilbron, The sun in the church: cathedrals as solar observatories (Cambridge, MA: Harvard University Press, 1999), 66-7.

71. This episode is described in Heilbron, Sun in the church (ref. 70), 67-8.

72. The following discussion of the obliquity of the ecliptic and trepidation is drawn from Jerzy Dobrzycki, "The theory of precession in medieval astronomy," in idem, Selected papers on medieval and renaissance astronomy, ed. Jaroslaw Wlodarczyk and Richard L. Kremer (Warsaw: Institute for the History of Science, Polish Academy of Sciences, Copernicus Center for Interdisciplinary Studies, 2010), 15-60.

73. Trepidation refers more broadly to a model of the precession of the equinoxes, of which the oscillation in size of the obliquity of the ecliptic was a part. For a fuller discussion, see Dobrzycki, "Theory of precession" (ref. 72).

74. Muḥammad ibn Jābir al-Ḥarrān̄̄ al-Battānī (c. 858-929).

75. Al-Zarqali or Ibn Zarqala (1029-1087).

76. Danti, La Sfera (1571), 28 (ref. 62).

77. "Che la Zona torrida, e le due frigide sieno inhabitabili, Christoforo Colombo nel anno 1491 c'ha mostrato esser falso.” Danti, La Sfera (1571), 34-35 (ref. 62).

78. "ho visto per una coppia di lettere del detto Colombo scritte di Siviglia al molto dotto, \& perito Matematico Messer Paolo Toscanella Fiorentino" Danti, La Sfera (1571), 35 (ref. 62).

79. On Toscanelli, see G. Abetti, "Toscanelli Dal Pozzo, Paolo" Complete dictionary of scientific biography. Vol. 13. (Detroit: Charles Scribner's Sons, 2008), 440-1.

80. Henry Vignaud, Toscanelli and Columbus (London: Sands \& Co., 1902), 46. Vignaud discusses this particular annotation in Danti's La Sfera on pp. 44-46.

81. "Onde se sarano due città l'una delle quali sia di forma pentagona come Perugia, \& l'altra di forma rotonda come quasi è Firenze molto piu capace sara Firenze che Perugia, anchor che siano d'equal circuito di mura ...” Danti, La Sfera (1571), p. 11 (ref. 62).

82. “Quanto magior è la latitudine, ò altezza del'Polo d'una regione, tante piu stelle verso quel'Polo non tramnotano mai, come verso il Polo Artico avvien qui à Perugia, dove mai tramonta ne l'Orsa minore, ne il Dragone, ne Ceffeo, ne la Caßioppea, \& di queste immagini nessuna stella tramonta mai, \& di alcune altre, ne restano parte sopra l'Orizonte, come del'Orsa maggior del Serpentario \& altre.” Danti, La Sfera (1571), 13-14 (ref. 62).

83. "quasi in una medesima latitudine con Amasia patria die Strabone" Danti, La Sfera (1571), 34 (ref. 62).

84. Thomas Hill, The schoole of skil containing two bookes: the first, of the sphere, of heauen, of the starres, of their orbes, and of the earth, \&c. The second, of the sphericall elements, of the celestiall circles, and of their vses, \&c. Orderly set forth according to art, with apt figures and proportions in their proper places, by Tho. Hill (London: Printed by T. Iudson, for W. Iaggard, 1599.) We have used the reproduction of the copy in the Henry E. Huntington Library and Art Gallery that is available in Early English Books Online. This copy is lacking some pages, and is assembled incorrectly (pages are out of order). We have also used a facsimile edition: Thomas Hill, The Schoole of Skil, London, 1599 (Amsterdam and New York: Da Capo Press, 1973).

85. Hill, Schoole of Skil, 42-45 (ref. 84).

86. Biographical information on Thomas Hill from John Considine, "Hill, Thomas (c.1528c.1574)" in Oxford dictionary of national biography, online ed., ed. Lawrence Goldman, Oxford: OUP, http://www.oxforddnb.com/view/article/13303 (accessed March 3, 2014); Francis R. Johnson, “Thomas Hill: An Elizabethan Huxley” Huntington Library Quarterly 
vii (1944), 329-51; and Johnson, Astronomical thought (ref. 16).

87. The gardening book is particularly famous. See Ellen C. Eyler, Early English gardens and garden books (Ithaca, N.Y: Cornell University Press, 1963) and Rosemary Verey, "English gardening books" in John Harris (ed.), The garden: a celebration of one thousand years of British gardening (London: Mitchell Beazley for the Victoria and Albert, 1979).

88. Katherine Anne Tredwell, "The exact sciences in Lutheran Germany and Tudor England" (Ph.D. dissertation, University of Oklahoma, 2005); on Peucer's book see pp. 131-135; on Hill's book see pp. 225-230.

89. Tredwell, "Exact sciences," p. 133.

90. This book was first published in 1550: Caspar Peucer, De dimensione terrae et fontibvs doctrinae longitvdinis et latitvdinis locorvm (Wittebergae: Haeredes Petri Seitzii, 1550), digitized version from the Bayerische Staatsbibliothek available through the Münchener Digitalisierungszentrum, Bayerische Staatsbibliothek. Revised and expanded editions appeared in 1553, 1579 and 1587: Caspar Peucer, De dimensione terrae et geometricae nvmerandis locorum particularium interuallis ex doctrina triangulorum sphaericorum \& canone subtensarum liber (Wittebergae: Johannes Crato, 1553), digitized version from the Regensburg Staatliche Bibliothek available through the Münchener Digitalisierungszentrum, Bayerische Staatsbibliothek; Caspar Peucer, De dimensione terrae et geometricae nvmerandis locorum particularium interuallis ex doctrina triangulorum sphaericorum \& canone subtensarum liber

(Witebergae: Lufft, 1579), digitized edition available through the Universitätsbibliothek Mannheim; and Caspar Peucer, De dimensione terrae et geometricae nvmerandis locorum particularium interuallis ex doctrina triangulorum sphaericorum \& canone subtensarum liber (Witebergae: Simon Gronenberg, 1587), digitized version from the Bayerische Staatsbibliothek available through the Münchener Digitalisierungszentrum, Bayerische Staatsbibliothek. These later editions include more diagrams and tables (two of which are reproduced in Hill's Schoole of Skil) and additional sections on the geography of the Holy Land. We presume Hill used the 1553 edition, which contains some material not in the 1550 edition. As Hill is supposed to have died around 1574, he would not have seen the 1579 or 1587 editions. Accordingly, we have compared passages in the Schoole of Skil with the 1553 edition of Peucer.

91. Hill, Schoole of Skil, 158 (ref. 84). The corresponding passage in Peucer is as follows: "In Atlantico mari America, inventoris nomine celebris, anno 1497 innotuit, a Lusitanis mandato \& sumptibus Castiliae regis indagata. Ea tantae esse magnitudinis perhibetur, ut quarta pars orbis habitati censeatur. Medium eius habet longitudinem 330 graduum, latitudinem 10 gradum Austrinam. In occiduo ambitu Americae regio Peru, auri ditißima \& feracißima aromatum, explorata Caroli V Imperatoris sumptibus Anno 1530, longo ductu septentrionem petit. Americae Mauritaniam versus \& Hispaniam Atlanticum mare obducitur plurimis refertum et spaciosißimis Insulis, inter quas sunt celebriores Spagnolla, Cuba, Parias quae potius Chersonensus angusto Isthimo sursum prorepit in septentrionem. Medium eius habet longitudinem 285 grad: latitudinem Borealem 44 grad: Nam ab 11 ad 50 fere usque producitur. In meridiem procul excurrit ultra Tropicum Capricorni America, etsi Australis eius ora nondum pervestigata est." Peucer, De dimensione terrae (1553), 63-64 (ref. 90).

92. For biographical information on William Jaggard, see Stanley Wells "William Jaggard (c1568-1623), printer and bookseller" in Oxford dictionary of national biography; Steven Max Miller, "William Jaggard; Isaac Jaggard; John Jaggard." The British literary book trade, 1475-1700, James K. Bracken and Joel Silver (eds.) (Detroit: Gale Research, 1996). Web. 6 June 2014; and Edwin Eliott Willoughby, A Printer of Shakespeare: The books and times of William Jaggard (New York, 1934).

93. Hill, Schoole of Skil, fol. A3v (ref. 84). 
94. All quotes from the Oxford English Dictionary. J. Dee in H. Billingsley tr. Euclid Elements Geom. Pref. sig. aiiij, (1570).

95. Harkness, The jewel house (ref. 16), 98. See also Kathryn James, "Reading numbers in early modern England," British society for the history of mathematics bulletin xxvi (2011), 1-16, 5.

96. Hill, Schoole of Skil, fol. A4 (ref. 84).

97. Hill, Schoole of Skil, 84, 93-94 (ref. 84).

98. Hill, Schoole of Skil, 86, 139 (ref. 84).

99. Hill, Schoole of Skil, 97 (ref 84).

100. Hill, Schoole of Skil, 96, 139, 152 (ref. 84).

101. Hill, Schoole of Skil, 94 (ref. 84).

102. Hill, Schoole of Skil, 249 (ref. 84).

103. Hill, Schoole of Skil, 250, and repeated with slight variation on 267 (ref. 84).

104. Hill, Schoole of Skil, 259 (ref. 84).

105. Hill, Schoole of Skil, 267 (ref. 84).

106. Hill, Schoole of Skil, 267 (ref. 84).

107. Hill, Schoole of Skil, 161 (ref. 84). The corresponding passage in Peucer is as follows: "Si Aequatori subiecta sint loca, quorum intercapedo queritur, arcus differentiae longitudinis idem est cum arcu distantiae, neque ab Aequatore differt circulus verticalis. complectitur enim tunc Aequator loci utriusque verticalia puncta, ut in triangulo $\alpha, \beta, \gamma$. Quare si in differentiae longitudinis partes ducantur 15 miliaria germanica, scrupula si qua adhoerent dividantur per 4 (tot enim unius gradus scrupulis unum congruit miliare germanicum) conficietur distantia. Ptolemaeo sub Aequatore sita sunt." Peucer, De dimensione terrae (1553), 108-109 (ref. 90).

108. Hill, Schoole of Skil, 164 (ref. 84). The corresponding passage in Peucer is as follows: "Dantisci longitudo 39 grad: 2 scrup: latitudo 54 grad: 48 scrup: Lubeci longitudo 28 grad: 20 scrup: latitudo 54 grad: 48 scrup: Differentia lonitudinis 10 grad: 42 scrup: dimidia differentia 5 grad: 21 scrup: sinus eius 9323 . Arcus complementi alterius aequalium latitudinum 35 grad: 12 scrupul: Sinus eius 57643. Hoc amplificato sinu dimidiae differentiae longitudinis, eoque quem constituit multiplicatio, numero diviso in sinum totum, provenit sinus 5374, cui in Canone respondent 3 grad: 5 scrupula. Dupli, id est, 6 graduum, 10 scrup:, gradus ducti in 15, scrupula divisa in 4 distantiam pariunt Lubeci \& Dantisci, quae est 92 miliarium cum semisse." Peucer, De dimensione terrae (1553), 123-124 (ref. 90).

109. Hill, Schoole of Skil, 175 (ref. 84).

110. Hill, Schoole of Skil, 210 (ref. 84).

111. Hill, Schoole of Skil, 176 (ref. 84). 